\title{
Eustatic and Relative Sea Level Changes
}

\author{
Alessio Rovere ${ }^{1,2}$ (I) $\cdot$ Paolo Stocchi ${ }^{3} \cdot$ Matteo Vacchi $^{4}$
}

Published online: 2 August 2016

(C) Springer International Publishing AG 2016

\begin{abstract}
Sea level changes can be driven by either variations in the masses or volume of the oceans, or by changes of the land with respect to the sea surface. In the first case, a sea level change is defined 'eustatic'; otherwise, it is defined 'relative'. Several techniques can be used to observe changes in sea level, from satellite data to tide gauges to geological or archeological proxies. Regardless of the technique used, 'eustasy' cannot be measured directly, but only calculated after perturbing factors of different origins are taken into account. In this paper, we review the meaning and main processes that contribute to eustatic and relative sea level changes, and we give an overview of the different techniques used to observe them.
\end{abstract}

Keywords Sea level changes $\cdot$ Eustasy $\cdot$ Relative sea level · Isostasy · GIA · Sea level

This article is part of the Topical Collection on Sea Level Projections

Alessio Rovere

arovere@marum.de

1 MARUM, University of Bremen, Leobener Straße, 28359 Bremen, Germany

2 ZMT, Leibniz Center for Tropical Marine Ecology, Fahrenheitstraße 6, 28359 Bremen, Germany

3 NIOZ Royal Netherlands Institute for Sea Research, Department of Estuarine and Delta Systems (EDS), Utrecht University, P.O. Box 59, 1790 AB Den Burg, Texel, The Netherlands

4 Aix-Marseille Université CEREGE CNRS-IRD UMR, 34, Europole de l'Arbois BP 80, 13545 Aix-en-Provence Cedex 4, France

\section{Introduction}

The term 'eustasy' was coined by the Austrian geologist Edward Suess in 1888 (later translated in English in 1906 [1]) and derives from the ancient Greek words $e u$, 'well', and statikos 'static, fixed'. The original definition was introduced by Suess to explain the observation that sea level is characterized by transgression and regression phases that respectively inundate and expose continental shelves. In Suess's original view, shorelines identified below and above the modern sea level could be directly linked (at the net of tectonic movements) to eustatic sea level during glacial and interglacial periods. This refers to the basic concept that, during glaciations, sea level lowstands were caused by storage of water in form of ice sheets on land, as well as by ocean density variations induced by lower global temperatures. The opposite occurs during interglacial periods, warmer than today, when the retreat of northern and southern hemisphere ice sheets beyond their current size, together with temperature-induced thermal expansion of ocean water, resulted in higher-than-present sea levels.

According to Suess's definition of eustasy, ocean mass variations following ice sheet fluctuations would result in global uniform mean sea level changes. This definition implies that the world's ocean basins are similar to a giant bathtub [2], with fixed borders represented by continents with sharp and steep boundaries. However, ice- and water-load variations trigger solid Earth deformations, gravitational and rotational perturbations that give rise to spatially varying sea level changes $[3 \bullet \cdot]$. In other words, both mean sea level and solid Earth surface move vertically with respect to each other and contribute to uneven topographic and bathymetric variations, changing the shape of the 'bathtub' as sea level changes. This, as well as other factors, causes sea level changes that are defined as 'relative', as land and ocean move with respect to each other. 
The reconstruction of eustatic sea level at different time scales is mostly of interest for the study of ice melting or warming of water masses, whereas relative sea level changes are often used to investigate regional to local processes. Although it might seem counterintuitive, it is possible that the combination of several processes in one area may result in a relative sea level rise even under conditions of global eustatic sea level fall.

While the concepts summarized above are clearly defined and commonly used by scientists working in the fields of geology [4], geodesy [5•] and geophysics $[6,7,8 \bullet \bullet$, they have implications that are relevant to a larger number of sciences, e.g. biogeography, macroevolution, macroecology $[9,10]$, archeology [11, 12], social sciences [13•] or cultural heritage conservation [14]. The many subtleties in the definition of eustatic and relative sea level changes often result confusing for a non-expert in these other disciplines. Therefore, the overarching aim of this paper is to give a concise but comprehensive account of the processes contributing to eustatic and relative sea level changes, together with an overview of how sea level changes are measured at different time scales. For more detailed synopses, the reader is referred either to the literature referenced in the text or to more organic treaties on the topic 'sea level' $[8 \bullet \bullet, 15,16]$.

\section{Eustatic Sea Level Changes}

Eustatic sea level (ESL) changes are driven by different processes that cause changes in the volume or mass of the world ocean $[17,18]$ and result in globally uniform mean sea level variations. ESL changes, therefore, are independent from local factors (such as tectonics moving a coastal area upwards) and are, by definition, global. Changes in mass of the world ocean occur either as a consequence of melting or accumulation of continental ice sheets over time (glacio-eustasy, Fig. 1a), and as a consequence of water redistribution between different hydrological reservoirs (snow, surface water, soil moisture, and groundwater storage, excluding glaciers [19]: hydroeustasy, Fig. 1b). Changes in volume, instead, are caused by variations in ocean water density as a result of cooling or warming of water masses (thermical expansion, Fig. 1c), or changes in their salinity (respectively, thermo- and halo-steric changes). ESL changes also occur when the volume of the ocean basins changes [20] following tectonic seafloor spreading (tectono-eustasy, Fig. 1d) or sedimentation (sedimentoeustasy). It is worth noting that, while the first four processes are mostly driven by climatic forcing, the latter two are driven by geological forces (Fig. 1).

Due to the different processes that can drive them, ESL changes can occur at very different time scales (Fig. 1e). Tectono- and sedimento-eustasy may cause sea level to change few hundreds of meters in 10-100 million years [21]. At shorter time scales, instead, glacio- and hydro- eustasy and steric changes to hundreds of meters [17]. Nevertheless, these processes are also significant at shorter time scales, although with lower magnitudes. As an example, it is estimated that glacio-eustasy is contributing to the ongoing sea level rise with a rate of $\sim 1.5 \mathrm{~mm} /$ year [19].

At shorter time scales, most of the recorded ESL changes are due to coupled ocean-atmosphere processes ('dynamic changes' in Fig. 1). These often trigger processes of hydroisostasy, thermo- or halo-steric changes. When the direct effects of these processes are only related to the shifting of water masses, they cannot strictly defined eustatic, as the global mean sea level does not change. For example, due to water masses shifting in the Pacific during strong El Niño events (1982-1983, 1997-1998), the western Pacific islands record a fall in sea level in the order of $30 \mathrm{~cm}$ while the eastern Pacific equatorial areas record a sea level rise of the same magnitude [22]. Because this process does not cause a change in global mean sea level, the changes recorded in the western and eastern Pacific are not eustatic in nature. Indirect effects of ENSO, though, can affect ESL inducing changes in land water storage. In fact, during El Niño, the ocean masses grow due to higher precipitations in the ocean and lower precipitation on land [23]. This causes a global mean sea level rise, which can be also observed in satellite altimetry datasets and can be considered a rapid, hydro-eustatic sea level change. This is defined as a dynamic ESL change (Fig. 1), and its duration can be quantified in years. In fact, this disequilibrium is eventually balanced during La Niña conditions.

\section{Relative Sea Level Changes}

Land uplift or subsidence can result in, respectively, a fall or rise in sea level that cannot be considered eustatic as the volume or mass of water does not change. Any sea level change that is observed with respect to a land-based reference frame is defined a relative sea level (RSL) change [24]. In the following sections, we give an overview of the main processes that can cause RSL changes. Most of them are not related to climatic causes (Fig. 2) and can act over a large span of spatial and temporal scales [25].

\section{Glacio Isostatic Adjustment and Gravitational Attraction}

Glacio isostatic adjustment (GIA; Fig. 2a, b) is defined as the 'viscoelastic response of the Earth to the redistribution of ice and ocean loads' $[3,26]$. In simpler words, this means that, given their densities, ocean water and continental ice exert weight onto the solid surface of the Earth. When an ice sheet grows, atmospheric air is replaced by denser ice, and, hence, a new isostatic equilibrium (that is, the gravitational equilibrium between Earth's crust and mantle) must be reached. As a 
Fig. 1 Processes contributing to ESL changes. a Glacio-eustatic changes due to glacier melting. b Hydro-eustatic changes due to changes in snow accumulation and surface water storage. Note that both $\mathbf{a}$ and $\mathbf{b}$ trigger isostatic RSL responses, exemplified in Fig. 2a, b. $\mathbf{c}$ Thermal expansion of water masses (thermosteric changes) at molecular level. Above $4{ }^{\circ} \mathrm{C}$, water expands as it is heated due to greater molecular motions. d Schematic example of volume changes due to changes in the volume of ocean basins. $\mathrm{e}$ Amplitude and duration of processes causing ESL changes (data from Gornitz et al., 2005 Table E8, [17])

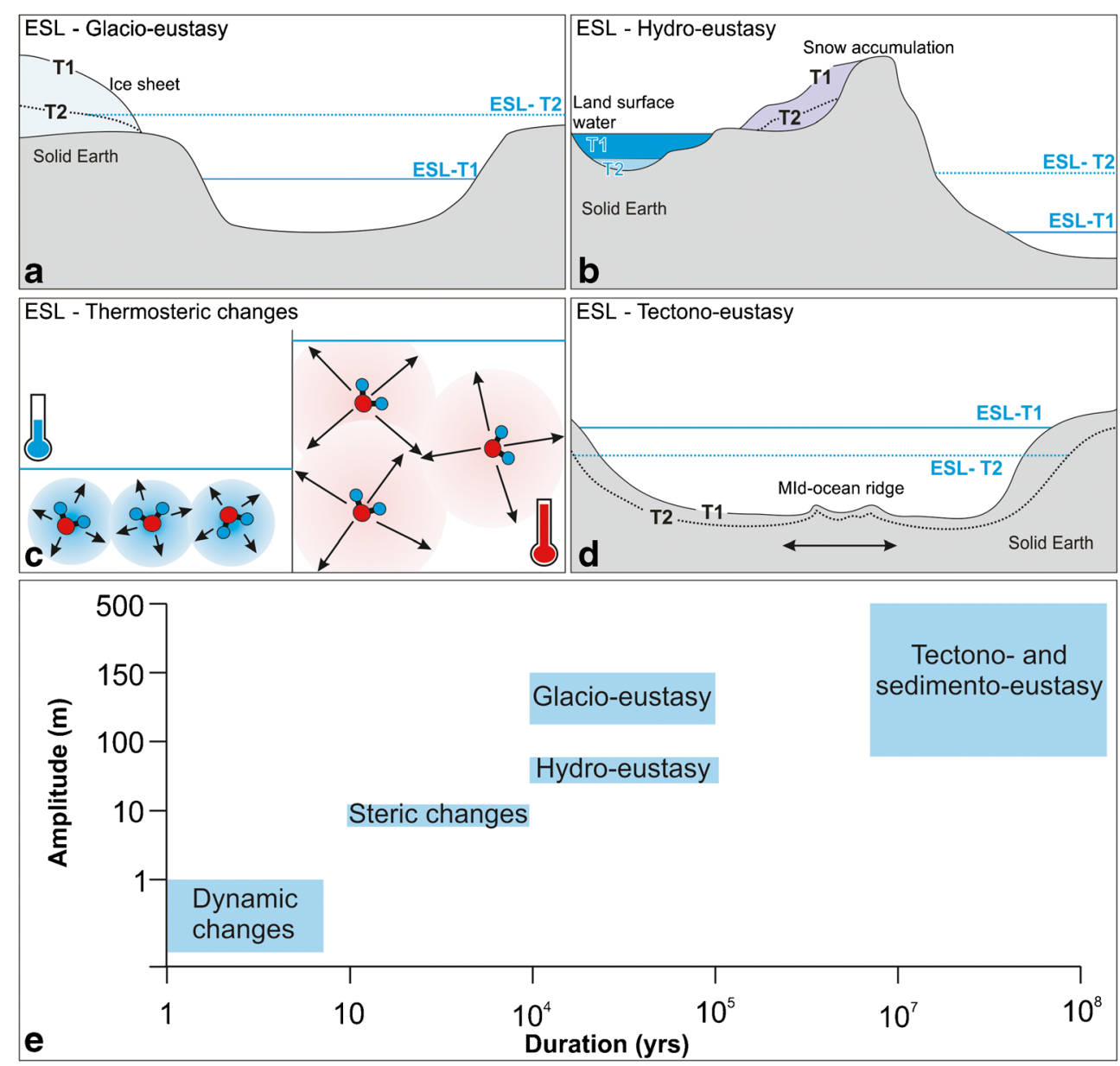

consequence, the ice-covered area undergoes subsidence, which is partly caused by the flexure of the lithosphere (outer shell of the solid Earth). The lithosphere, in fact, behaves like an elastic body (Hooke's law) and immediately responds to the surface load increase. However, as the base level of the lithosphere sinks into the mantle, a viscous flow is triggered and mantle material slowly moves outwards from the glaciated area and upwards outside of the ice margins (Fig. 2a). Accordingly, an uplifting peripheral forebulge, which exacerbates the relative sea level drop, is generated around the ice sheet. The same processes that characterize the ice-proximal ('near field') areas during a glaciation also affect the ocean basins far away from the ice sheets ('far field'). Here, the removal of water triggers solid Earth uplift (due to hydroisostasy) in the bulk of the basins and a slight subsidence along the continental margins due to lithospheric flexure (Fig. 2a). Trivially, the so far described solid Earth processes are reversed when the ice sheet melts (Fig. 2b).

During the glacial periods, depression of land beneath ice sheets caused migration of mantle material away from ice load centers, resulting in uplift of the forebulge in those regions adjacent to ice sheets (intermediate-field regions [25, 27]). Transition from glacial to interglacial conditions triggers the progressive collapse of this forebulge, as land-based ice diminished and mantle material returned to the former load centers (Fig. 2b). This induces glacio-isostatic subsidence, an important factor controlling RSL changes at the periphery of former ice sheets $[8 \bullet \bullet, 28]$. The subsidence of the forebulges exerts a control of sea level change also in far-field regions such as the equatorial areas. Here, in fact, water moves and migrates towards the collapsing peripheral forebulges (northern and southern hemisphere) in order to compensate for the local increase in bathymetry and to conserve mass. This process is known as 'equatorial ocean syphoning' and, during the late Holocene, has resulted in a prominent RSL drop that can be observed nowadays in form of a Holocene highstand in areas such as the Pacific islands [29]. A second mechanism also contributes to RSL drop during the final stage of postglacial sea level rise and along the continental margins of farfield areas. It is called 'continental levering' (Fig. 2b) and is the result of an upward tilt of the coastal sectors of continents in response to the increase of water load within the ocean basins [30]. Sea bottom undergoes subsidence and upper mantle material is pushed towards the continents. At the same time, the lithosphere flexes and, as a result, coastal areas experience uplift that drives a local RSL fall. 

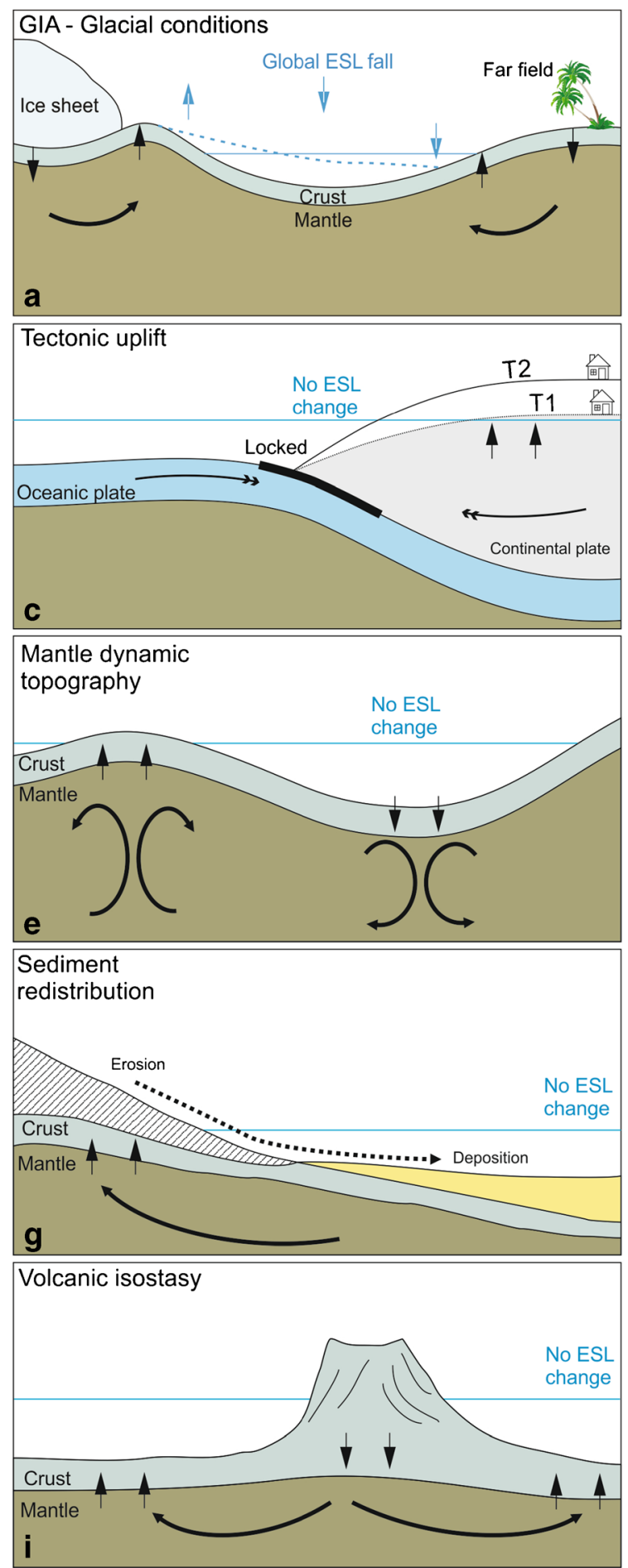
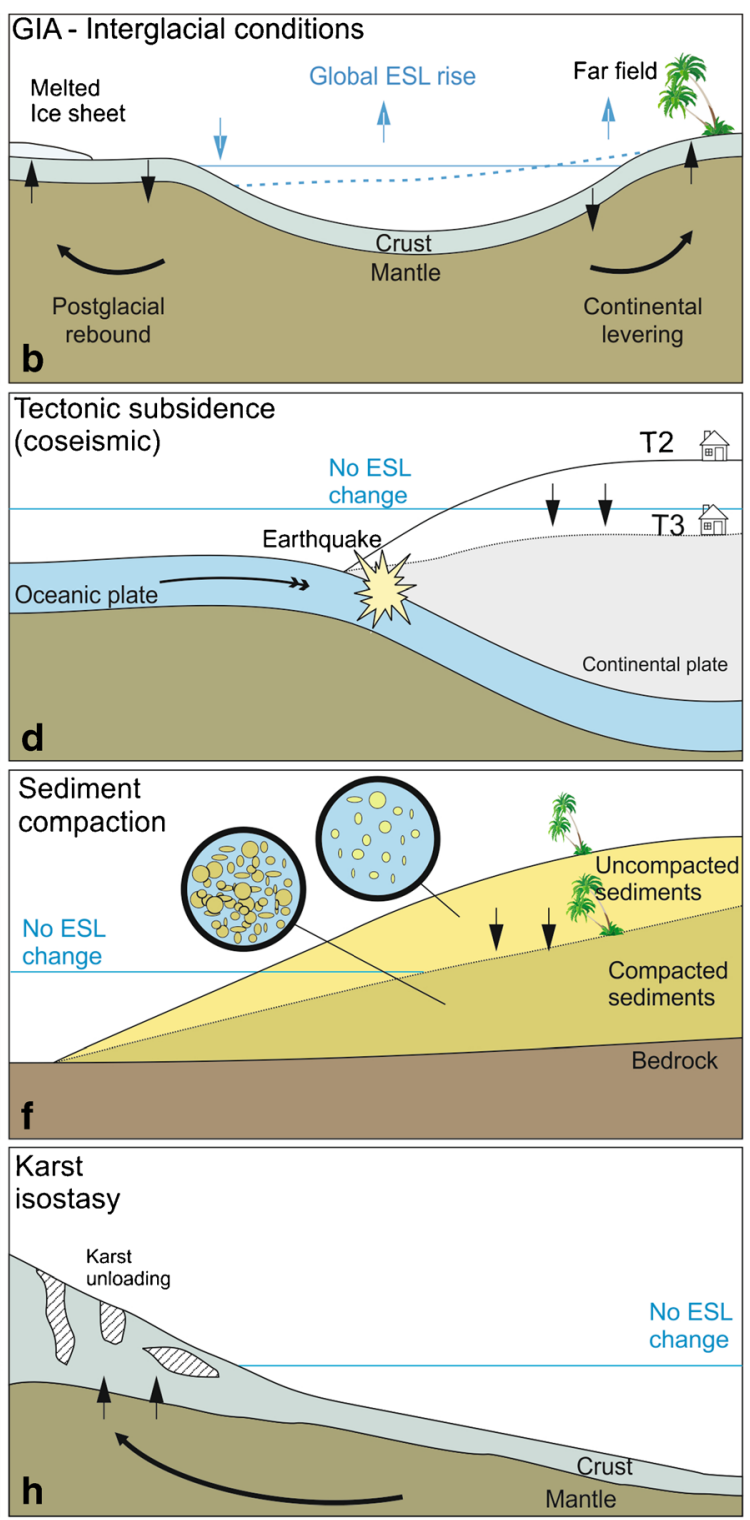

Extraction of natural resources
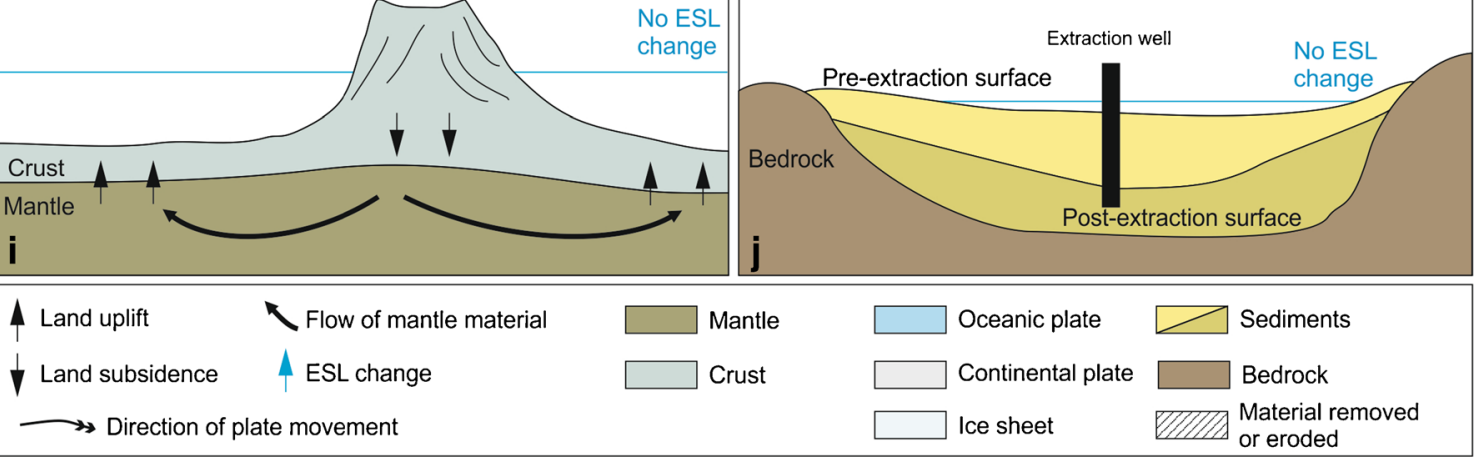

(crustal uplift) in case of converging mantle flow movements. f Sediment compaction causing RSL rise. $\mathbf{g}$ Isostatic adjustment due to the redistribution of sediments, specifically following erosion from the coastal plain and deposition on the continental shelf. $\mathbf{h}$ Isostatic adjustment following karst dissolution. i Volcanic isostasy. $\mathbf{j}$ RSL change caused by extraction of natural resources (e.g. groundwater) 
Another effect associated with GIA is gravitational attraction. Given their mass, ice and ocean water experience a mutual gravitational attraction. When an ice sheet grows, the mutual gravitational pull attracts water masses towards it (Fig. 2a, blue dotted line: water is pulled towards the ice sheet). When the ice sheet melts, the pulling forces on the water decrease, with a net effect of RSL fall in the near field and a RSL rise in the far field (Fig. 2b). This process is called gravitational attraction, or 'self-gravitation', and is a fundamental component of the GIA process. The pattern created by this redistribution of water masses is often referred to as sea level 'fingerprint' $[2,31 \bullet \cdot$. The term fingerprint refers to the fact that each ice sheet melting will produce a very specific spatial signature on the way the water is redistributed (dictated by self-gravitation and Earth rotation [31••]), due to its location on the Earth surface.

Given the processes that define GIA, it follows that glacioeustatic sea level changes represent a special case of more general ice-induced relative sea level changes. In fact, by neglecting gravity and solid Earth deformations, any ice sheet fluctuation would result in a global uniform RSL change. This also means that the ocean average of GIA-induced RSL change is equal to the hypothetical glacio-eustatic sea level changes simply because of mass conservation. Although the spatial complexity of GIA seems to obscure the ESL change values, it is the actual pattern of GIA-driven RSL fingerprints that contributed to the geographically constrained reconstructions of ice sheet thickness variations through time. In fact, if the oceans were to behave like a bathtub (i.e. eustatically), there would be not enough information about the location of former continental ice sheets. It would be impossible to locate the source of meltwater release during deglaciations.

\section{Tectonic Deformations and Dynamic Topography}

Along active margins, RSL changes can be caused by vertical movements due to tectonic forces [32]. In simple words, a shoreline moving upwards or downwards due to the presence of systems of faults can experience a coseismic or post-seismic RSL fall or rise. In Fig. 2c, d, we show a classic example that illustrates how RSL is affected, along a subduction zone, by interseismic uplift (Fig. 2c) and coseismic-related subsidence (Fig. 2d [33, 34]). In general, tectonic uplift or subsidence is considered one of the primary causes of RSL changes, both at longer (e.g. Holocene [32, 35, 36] or Quaternary [37, 38]) and shorter time scales (e.g. last century [39, 40]).

In contrast with active margins, passive ones are often considered as tectonically stable. In these areas, tectonics could be in fact negligible at short time scales, but vertical movements due to mantle dynamic topography may affect RSL on longer time scales. Mantle dynamic topography is caused by mantle flow that drives significant vertical motions of the crust along large areas (Fig. 2e, [41]). Mantle dynamic topography effects are particularly relevant at time scales of few millions of years $[42,43]$, but it cannot be excluded that they may play a role also in displacing late Quaternary RSL records $\left[44,45^{\circ}\right]$. We remark that, while in Earth sciences, 'dynamic topography' is used with the meaning outlined above, in oceanography, the same term is used to define the variations of the ocean surface topography, which are relevant to studies using satellite altimetry to reconstruct sea level changes.

\section{Sediment Compaction}

The sediments deposited in a coastal area can be subject, through time, to loss of volume. This causes land subsidence, and therefore a RSL rise. There are several mechanical (e.g. consolidation of sediments), biological (e.g. biochemical degradation) and human-driven (e.g. land drainage) processes that can either cause or accelerate sediment compaction (see Brain, 2016 [46] for a recent overview of the aforementioned processes). In Fig. 2f, we exemplify how RSL fall is caused by a sediment progressively losing its porosity and expelling interstitial water due to the effects of loading of younger sediments. This process can affect a coastal area in a spatially different way. As an example, the volume of sediment that can be compacted is related to the depth at which the incompressible substrate (e.g. the bedrock, Fig. 2f) is located. As the depth of the bedrock can vary spatially, the total subsidence of a coastal area can vary across it [47]. Along large river estuaries, such as the Nile [47] or the Mississippi delta [48], sediment compaction is responsible for several meters of subsidence, and hence RSL rise, during the last millennia. Subsidence due to sediment compaction is one of the major drivers of current RSL rise in many highly populated deltas [49].

\section{Sediment, Karst and Volcanic Isostasy}

Isostatic responses can happen not only when ice sheet or glacier masses are removed (glacial isostatic adjustment) but also when large quantities of sediments are redistributed along the coast [50]. Similarly to what happens for ice sheets, the loading/unloading of sediments can cause a net flow of mantle material from the area loaded of sediments towards the area where the sediments have been eroded (Fig. 2g). A similar process affects areas that have been subject to karst erosion, where a significant load on the crust has been decreased, with no loading in other areas (Fig. 2h, [51]). Sediment and karst isostasy have been, until recently, overlooked in sea level studies, but they are likely to have a major effect on RSL histories at millennial and longer time scales [50]. Another similar process is that of the isostatic response to volcanic loading [52], which is triggered by the loading of the lithosphere by a volcanic edifice (Fig. 2i). 


\section{Human Activities}

Some types of human activities may cause subsidence of the land level in coastal areas, and hence result in a RSL rise [13•]. In general, human activities triggering subsidence rates are soil drainage (e.g. for urban development purposes) or subsurface mining of resources such as groundwater, oil or gas [53]. The magnitude of RSL rise caused by human activities is often considerable, in the range of few meters in few tens of years [54]. In coastal cities of Indonesia, for example, gas and groundwater extractions contribute to subsidence rates up to $22 \mathrm{~cm} /$ year [55]. In the Po delta, in Italy, large withdrawals of methanerich groundwater between 1950 and the early 1970s caused a land subsidence of up to $3 \mathrm{~m}$ [56]. In general, extraction activities cause higher subsidence rates near the extraction centers (Fig. 2j) and they have similar effects on sediment compaction.

\section{Observing Sea Level Changes}

Changes in sea level can be observed at very different time scales and with different techniques. Regardless of the technique used, no observation allows to record purely eustatic sea level changes. At multi-decadal time scales, sea level reconstructions are based on satellite altimetry/gravimetry and landbased tide gauges [57]. At longer time scales (few hundreds, thousands to millions of years), the measurement of sea level changes relies on a wide range of sea level indicators [45 , 58, 59]. In the following sections, we briefly describe these observation techniques and the relationship of observed values with ESL.

\section{Multi-Decadal Sea Level Changes}

One of the most common methods to observe sea level changes at multi-decadal time scales is tide gauges. Tide gauges measure the variations of sea level relative to a geodetic benchmark, a fixed point of known elevation above mean sea level. The tide gauge record extends, for some stations, back to the eighteenth century [60]. Notably, tide gauge records of at least 50 years (i.e. with minimized contamination by interannual and decadal variability) are considered a reliable dataset against which hypotheses of changing sea levels can be evaluated [61, 62]. Modern tide gauges are associated with a GPS station that records land movements (Fig. 3a). In fact, in order to reconstruct ESL changes from tide gauges, it is necessary to take into account vertical shifts of the land of both geological (e.g. due tectonics, Fig. 2) and human origin (e.g. due to groundwater extraction, Fig. 2), as well as all the noneustatic dynamic changes in sea level due to tides, storm surges, tsunamis and currents. Once all these effects are removed from the tide gauge record, different techniques can be used to harmonize the data gathered by a globally distributed tide gauge network into a single global mean sea level change signal $[63,64]$ (Fig. 3c). Tide gauges have three main disadvantages: (i) they are unevenly distributed around the world [65]; (ii) the sea level signal they record is often characterized by missing data [63]; and (iii) accounting for ocean dynamic changes and land movements might prove difficult in the absence of independent datasets. Nevertheless, tide gauges are a valuable recorder of coastal sea level changes and often the relative sea level signal recorded by tide gauges can be used to quantify potential sources of RSL rise, such as sediment compaction [66]. Also, our ability to reconstruct sea levels since the late 1800 s relies uniquely on the tide gauge record (Fig. 3c).

Since 1992, tide gauge data are complemented by satellite altimetry datasets [67] (through the consecutive TopexPoseidon and Jason missions). The principle used by satellite altimetry is that it measures the time taken by a radar pulse to travel from the satellite antenna to the sea surface and back to the satellite receiver. After corrections for interferences of the radar signal [68], the travelling time of the radar signal time is transformed into a distance, called 'range'. The orbit (and hence the altitude) of a satellite can be established with high accuracy (i.e. using DORIS and laser stations, as well as GPS satellites, Fig. 3a). The altitude of the satellite is established with respect to an ellipsoid, which is an arbitrary and fixed surface that approximates the shape of the Earth. The difference between the altitude of the satellite and the range is defined as the sea surface height (SSH). Subtracting from the measured SSH a reference mean sea surface (e.g. the geoid, or another reference mean sea surface [69]), one can obtain a 'SSH anomaly'. Every 10 days (satellite track repeat cycle) the calculation of the SSH anomaly at each point in the ocean is repeated. Once corrected for seasonal variations [5], due for example to ocean currents, and other factors such as glacial isostatic adjustment [70] (see also Kopp et al. (2015) their Fig. 3b-d [3]), the global average of all SSH anomalies can be plotted over time to define the global mean sea level change, which can be considered as the eustatic, globally averaged sea level change (Fig. 3b).

Satellite altimetry datasets are complemented by another type of satellite data that provides gravimetric measures, i.e. measures of the distribution of masses on the Earth and oceans. The force of gravity on the surface of the Earth is not constant, but rather a function of geographical location. In fact, gravity is affected by factors such as density anomalies in Earth's interior, the rotation of Earth as well as positive and negative topographic features. Gravimetric satellite measures, such as those provided by Gravity Recovery and Climate Experiment (GRACE) and Gravity field and steady-state Ocean Circulation Explorer (GOCE) missions, have been used to map the Earth's gravity field and its changes through time. The gravity field can be used, in turn, to calculate the height of the geoid, which is an equipotential surface of 

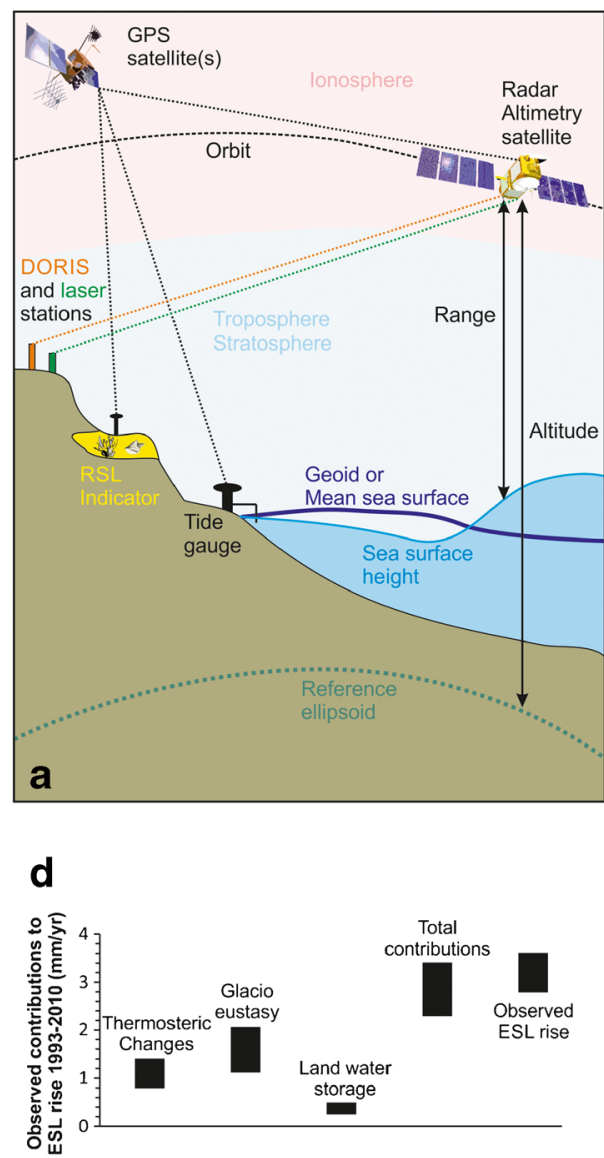

Fig. 3 a Different types of sea level observation techniques: satellite altimetry (based on NASA educational material), tide gauge and paleo sea level indicators (see text for details). b Global mean sea level change recorded by satellite altimetry, corrected and uncorrected for seasonal factors (respectively, black and gray lines [5•]). The 'zero' in this time series is referred to the CLSO1 mean sea surface. c Global mean sea level from the satellite altimetry record (red line, annual average of the data shown in b) compared with that obtained from tide gauge records by Church and White, 2011 (blue band [64]) and by Hay et al., 2015 (pink

gravity and, within the ocean areas, corresponds to the mean sea surface at rest. The shape of the geoid is crucial for deriving accurate measurements of seasonal sea level variations [71] (that must be subtracted from SSH as a non-eustatic component), geoid height (that can be used as a reference surface to compare with SSH anomalies) and the quantity of water stored in land reservoirs [72].

One of the main aims of current research focusing on multidecadal sea level changes is closing the budget between the global mean sea level change that is observed with satellite altimetry and the magnitude of the processes contributing to it [19]. The main causes of recent ESL changes can be identified in the expansion of water masses (steric changes, Fig. 3d) [73, 74], and glacier and ice sheet mass loss (glacio-eustasy, Fig. 3d) $[75,76]$. A third contribution that of hydro-eustatic processes

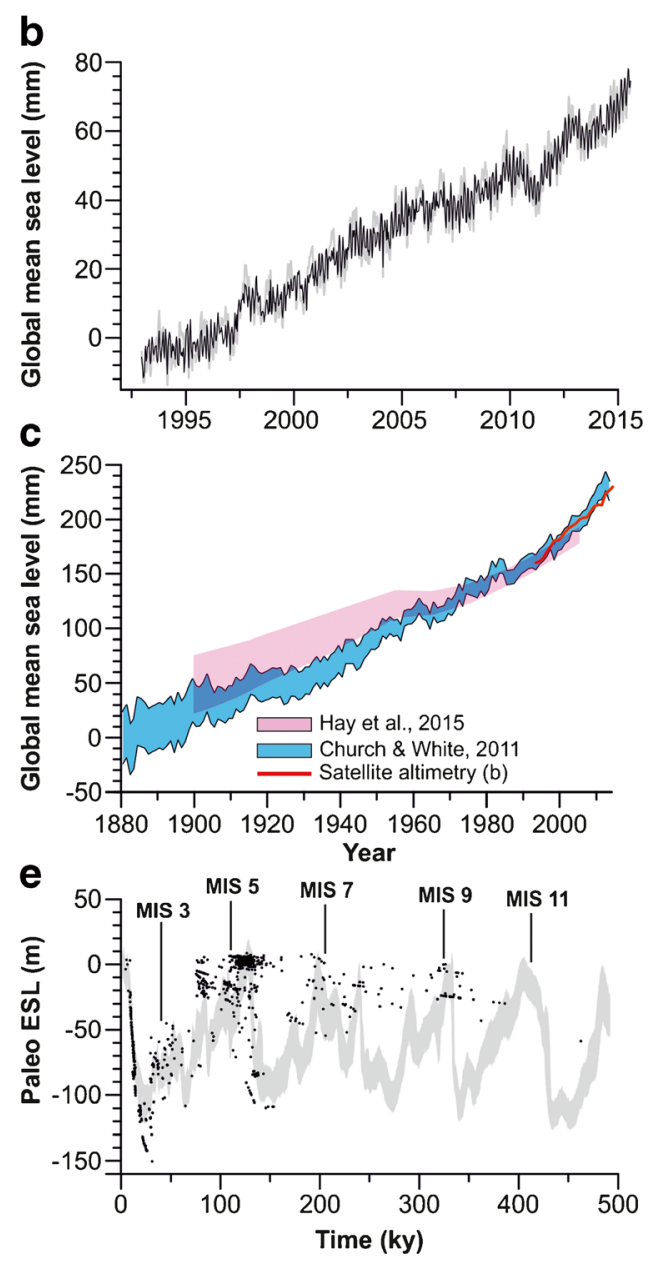

band [63]). d Observed contribution to the rate of current ESL rise in the period 1993-2010 (data from IPCC, Table 13.1, [19]). In this panel, land water storage is shown to contribute ESL rise by $\sim 0.3 \mathrm{~mm} / \mathrm{year}$ (as indicated by IPCC [19]), while recent studies instead argued that it halted the rate of recent sea level rise [72], so its contribution would be negative. e Paleo ESL estimates (with uncertainty, gray band) from $\delta \mathrm{O}^{18}$ records of Red Sea over the last 500,000 years [78]. Dots represent dated fossil corals and their elevation [93], and can be used, after interpretation of paleo water depth [92], as RSL indicators

on the current ESL rise is still debated and bounded by several uncertainties. These stem from estimates of land water storage, for which relatively little data is available. Until recently, several studies suggested that the loss of water from land storage could contribute to the observed ESL rise up to $\sim 0.4 \mathrm{~mm} /$ year (Fig. 3d) [19]. GRACE data allowed to quantify variations in groundwater storage and suggested that the storage of water in land reservoirs has halted the recent sea level rise by $\sim 15 \%$ [72], instead of contributing to it as previously assumed.

\section{Paleo Sea Level Changes}

While satellites and tide gauges can provide continuous records of sea level changes at multi-decadal time scales, at longer time scales (paleo sea level changes, few hundreds to millions of 
years), there is no such thing as an instrumental sea level observation. In order to gather insights on eustatic changes at longer time scales, it is necessary to reconstruct paleo sea level changes using proxies. The only proxy that allows to obtain continuous paleo sea level reconstructions through time is records of $\delta^{18} \mathrm{O}$ [77], which cannot be considered a direct sea level observation as they represent a convolute signal of ocean mass and sea temperature variations. These can be translated into paleo ESL changes (Fig. 3e), although with considerable uncertainty [78]. The only observations that have a direct relation to sea levels in the past are paleo sea level indicators, or RSL indicators (also called RSL index points, or RSL markers). In the simplest definition, a RSL indicator is any feature that was formed, deposited or constructed in connection with a former sea level. RSL indicators can be divided into two broad categories: archeological and geological.

Archeological remains of structures built at the interface between land and sea can be used as RSL indicators [59, 79]. These include, for example, ancient harbours or fish tanks (structures used to breed fishes in Roman times). The coupled analysis of ancient harbors and fossil marine organisms attached to waterfront structures has been recognized as the most precise source of archeological sea level data [80, 81]. In the absence of fossil remains, the paleo RSL reconstruction of an archeological structure is based on interpretation of its relationship with the former mean sea level [59]. This is commonly defined as the functional height [82] which corresponds to the elevation of a specific architectural part with respect to the mean sea level position at the time of its construction. The Mediterranean Sea is the richest location in terms of archeological RSL indicators. They are very useful indicators of the sea level variation of the last 2.5 thousand years BP, thanks to the heavy coastal colonization of the ancient Roman, Greek and Phoenician civilizations [59].

Geological RSL indicators (that include also fossil remains of fixed biological organisms [83]) are used to reconstruct RSL from few centuries [84] to hundreds of thousands of years [85] (Fig. 3d, e). In simple terms, a geological RSL indicator is any imprint left by a past sea level in the form of a deposit (e.g. a beach), a biological remain (e.g. a coral reef) or a landform (e.g. a marine terrace). Examples of geological RSL indicators are raised beaches, containing fossil shells and intertidal sedimentary structures [86], organisms that once were living in close connection with mean sea level, such as coral microatolls [87], or particular foraminiferal assemblages in saltmarsh and other types of coastal sediments [28]. As for archeological RSL indicators, the relationship of the RSL indicator with the former mean sea level and the uncertainty associated with it (i.e., the 'indicative meaning' of the indicator) must be known or estimated $[45 \cdot, 88 \cdot, 89]$. Also, the age of the RSL indicator must be known: it can be established with radiometric techniques (e.g. U-series or radiocarbon dating [90]) or inferred through indirect dating methods (e.g. chronostratigraphic or biostratigraphic correlations, often used for RSL indicators dating back more than few hundred thousands of years [43]).

Archeological and geological sea level indicators can be used to estimate the paleo RSL at the time of their construction or formation, with uncertainties that are associated with the measurement and interpretation of the indicator [45 $]$. In general, RSL indicators typically used in late Holocene RSL reconstructions, such as coral microatolls or foraminiferal assemblages in salt marshes [91], allow to reconstruct the elevation of a paleo RSL within few decimeters [88•]. For older time periods, such as the Pleistocene, sea level indicators might carry multi-metric uncertainties $[45 \cdot, 92]$ that propagate into the calculation of paleo ESL changes.

In order to obtain the paleo ESL from a paleo RSL datum, it is necessary to quantify and subtract from the paleo RSL all the processes described in Fig. 2, each carrying as well an uncertainty, which concurs to the standard deviation associated with the final ESL value. Some of the RSL processes can be quantified through modeling. As an example, GIA can be investigated using different iterations of GIA models with varying mantle viscosities or ice histories [90]. According to the study area where the RSL proxy is investigated, some of the terms can be considered uninfluential. As an example, karst isostasy can be ruled out in case there are no large carbonate areas that can influence the RSL proxy. Also, the time frame considered may help in excluding some of the processes. As an example, earth dynamic topography can be considered negligible at short time scales (e.g. tide gauge datasets, or Holocene RSL indicators), but proved to be a major obstacle in deriving consistent ESL estimates for the mid-Pliocene warm period ( $\sim 3 \mathrm{Ma})$ as different dynamic topography models calculate predictions spanning, in some places, up to hundreds of meters [43,44], with the result of making the uncertainties in field-based estimates of mid-Pliocene ESL very large.

\section{Conclusions}

One of the most debated effects of climate change is sea level changes. Sea level changes have the potential to cause large economic [94] and societal distress [95], and are directly relevant to several disciplines studying both social and ecological processes in coastal areas. The interest of climate sciences is often turned towards the causes and the magnitude of eustatic sea level changes at different time scales, which range from few years to millions of years. One of the complicating issues when studying sea levels is that, despite what is suggested by the classic definition of eustasy, sea level changes on Earth cannot be treated as if happening in a rigid container (i.e. a bathtub). Internal Earth processes (e.g. tectonics, earth dynamic topography), Earth surface processes (e.g. sediment compaction) and climate-driven processes (e.g. melting ice 
sheets) all trigger variations of the container, and they ultimately affect any sea level observation.

These processes make impossible to observe, at any location on Earth, a pure eustatic signal. As eustasy itself cannot be directly observed, eustatic sea level cannot be considered a physical sea level, but must be regarded more as a quantitative index that is used to characterize climate change, in terms of melting ice and variations in temperature or salinity. In order to quantify eustatic sea level changes, one needs to analyze either satellite or land-based datasets, taking into account all the processes that may cause the observation to depart from eustasy, and derive a global ESL estimate, that is necessarily bounded by uncertainties.

The interplay of eustatic and other processes triggers relative sea level changes. While eustasy is global by definition, relative sea level changes are regional or local in nature. As such, they are extremely important (often more important than global eustatic sea levels) to policy makers or scientists working on disciplines, such as ecology or social sciences, that aim to analyze the effects of sea level changes on specific regions: in certain areas, in fact, relative sea level changes can magnify the rates of rising eustatic sea levels [13•].

Acknowledgments AR's research is supported by the Institutional Strategy of the University of Bremen, funded by the German Excellence Initiative (ABPZuK-03/2014) and by ZMT, the Center for Tropical Marine Ecology. AR also acknowledge NSF grant OCE1202632 'PLIOMAX'. The authors acknowledge MEDFLOOD Modelling Paleo Processes (INQUA CMP projects 1203P and 1603P) and PALSEA (PAGES/INQUA/WUN) working groups for useful discussions. MV contributes $\mathrm{A}^{*} \mathrm{MIDEX}$ project $\mathrm{n}^{\circ} \mathrm{ANR}-11$-IDEX-0001-02). We thank J. Austermann (Harvard University) for reviewing an earlier version of Fig. 2.

\section{Compliance with Ethical Standards}

Conflict of Interest We declare no conflict of interest.

Human and Animal Rights and Informed Consent This article does not contain any studies with human or animal subjects performed by any of the authors.

\section{References}

Papers of particular interest, published recently, have been highlighted as:

- Of importance

• Of major importance

1. Suess E. The face of the earth. Oxford: Clarendon Press; 1906.

2. Hay C, Mitrovica JX, Gomez N, Creveling JR, Austermann J, Kopp RR. The sea-level fingerprints of ice-sheet collapse during interglacial periods. Quat Sci Rev. 2014;87:60.

3.• Kopp RE, Hay CC, Little CM, Mitrovica JX (2015) Geographic variability of sea-level change. Curr Clim Chang Reports 1:19220469 . Review of the processes that cause sea level to be spatially variable, with detailed discussion of GIA.
4. Chappell J. Geology of coral terraces, Huon Peninsula, New Guinea: a study of Quaternary tectonic movements and sea-level changes. Geol Soc Am Bull. 1974;85:553-70.

5. Nerem RS, Chambers DP, Choe C, Mitchum GT. Estimating mean sea level change from the TOPEX and Jason altimeter missions. Mar Geod. 2010;33:435-46. Overview of how global mean sea level changes are derived from satellite altimetry.

6. Peltier WR. Postglacial variations in the level of the sea: implications for climate dynamics and solid-earth geophysics. Rev Geophys. 1998;36:603-89.

7. Mitrovica JX, Milne GA. On post-glacial sea level: I. General theory. Geophys J Int. 2003;154:253-67.

8.• Milne GA, Gehrels WR, Hughes CW, Tamisiea ME. Identifying the causes of sea-level change. Nat Geosci. 2009;2:471-8. Review of the causes of eustatic and relative sea level changes.

9. Harley CDG, Randall Hughes A, Hultgren KM, Miner BG, Sorte CJB, Thornber CS, Rodriguez LF, Tomanek L, Williams SL. The impacts of climate change in coastal marine systems. Ecol Lett. 2006;9:228-41.

10. McKee K, Rogers K, Saintilan N (2012) Response of salt marsh and mangrove wetlands to changes in atmospheric $\mathrm{CO} 2$, climate, and sea level. In: Glob. Chang. Funct. Distrib. Wetl. Springer, pp 63-96

11. Van Andel TH. Late Quaternary sea-level changes and archaeology. Antiquity. 1989;63:733-45.

12. Ammerman AJ, McClennen CE, De Min M, Housley R. Sea-level change and the archaeology of early Venice. Antiquity. 1999;73:303-12.

13. Nicholls RJ, Cazenave A. Sea-level rise and its impact on coastal zones. Science. 2010;328:1517-20. Overview of the impacts of changing sea levels, also related to the vulnerability of coastal areas.

14. Marzeion B, Levermann A. Loss of cultural world heritage and currently inhabited places to sea-level rise. Environ Res Lett. 2014;9:34001.

15. Church JA, Woodworth PL, Aarup T, Wilson S (2010) Understanding sea level rise and vulnerability

16. Shennan I, Long AJ, Horton BP (2015) Handbook of sea-level research. Wiley

17. Gornitz V (2005) Eustasy. In: Encycl Coast Sci Springer, pp 439-442

18. Miller KG, Kominz MA, Browning JV, Wright JD, Mountain GS, Katz ME, Sugarman PJ, Cramer BS, Christie-Blick N, Pekar SF. The Phanerozoic record of global sea-level change. Science. 2005;310:1293-8.

19. Church JA, Clark PU, Cazenave A, et al (2013) Sea level change. Clim Chang 2013 Phys Sci Basis Contrib Work Gr I to Fifth Assess Rep Intergov Panel Clim Chang

20. Rona PA. Tectonoeustasy and Phanerozoic sea levels. J Coast Res. 1995:269-77.

21. Flemming NC, Roberts DG (1973) Tectono-eustatic changes in sea level and seafloor spreading

22. Widlansky MJ, Timmermann A, Cai W. Future extreme sea level seesaws in the tropical Pacific. Sci Adv. 2015;1:e1500560.

23. Cazenave A, Henry O, Munier S, Delcroix T, Gordon AL, Meyssignac B, Llovel W, Palanisamy H, Becker M. Estimating ENSO influence on the global mean sea level, 1993-2010. Mar Geod. 2012;35:82-97.

24. Kemp AC, Dutton A, Raymo ME. Paleo constraints on future sealevel rise. Curr Clim Chang Rep. 2015;1:205-15.

25. Khan NS, Ashe E, Shaw TA, Vacchi M, Walker J, Peltier WR, Kopp RE, Horton BP. Holocene relative sea-level changes from near-, intermediate-, and far-field locations. Curr Clim Chang Rep. 2015;1:247-62.

26. Milne GA, Mitrovica JX. Postglacial sea-level change on a rotating Earth. Geophys J Int. 1998;133:1-19.

27. Peltier WR. Global glacial isostasy and the surface of the ice-age Earth: the ICE-5G (VM2) model and GRACE. Annu Rev Earth Planet Sci. 2004;32:111-49. 
28. Engelhart SE, Horton BP. Holocene sea level database for the Atlantic coast of the United States. Quat Sci Rev. 2012;54:12-25.

29. Mitrovica JX, Milne GA. On the origin of late Holocene sea-level highstands within equatorial ocean basins. Quat Sci Rev. 2002;21: 2179-90.

30. Milne GA, Mitrovica JX. Searching for eustasy in deglacial sealevel histories. Quat Sci Rev. 2008;27:2292-302.

31.• Mitrovica JX, Gomez N, Clark PU. The sea-level fingerprint of West Antarctic collapse. Science. 2009;323:753 .Analysis of the spatially variable effect of melting of the West Antarctic Ice Sheet following GIA effects.

32. Dura T, Engelhart SE, Vacchi M, Horton BP, Kopp RE, Peltier WR, Bradley S. The role of holocene relative sea-level change in preserving records of subduction zone earthquakes. Curr Clim Chang Rep. 2016:1-15.

33. Leonard LJ, Hyndman RD, Mazzotti S. Coseismic subsidence in the 1700 great Cascadia earthquake: coastal estimates versus elastic dislocation models. Geol Soc Am Bull. 2004;116:655-70.

34. Dragert H, Hyndman RD, Rogers GC, Wang K. Current deformation and the width of the seismogenic zone of the northern Cascadia subduction thrust. J Geophys Res Solid Earth. 1994;99:653-68.

35. Vacchi M, Rovere A, Zouros N, Desruelles S, Caron V, Firpo M. Spatial distribution of sea-level markers on Lesvos Island (NE Aegean Sea): evidence of differential relative sea-level changes and the neotectonic implications. Geomorphology. 2012;159-160:50-62.

36. Shennan I, Long AJ, Rutherford MM, Green FM, Innes JB, Lloyd JM, Zong Y, Walker KJ. Tidal marsh stratigraphy, sea-level change and large earthquakes, I: a 5000 year record in Washington, USA. Quat Sci Rev. 1996;15:1023-59.

37. Simms AR, Rouby H, Lambeck K. Marine terraces and rates of vertical tectonic motion: the importance of glacio-isostatic adjustment along the Pacific coast of central North America. Bull Geol Soc Am. 2016;128:81-93.

38. Kelsey HM, Bockheim JG. Coastal landscape evolution as a function of eustasy and surface uplift rate, Cascadia margin, southern Oregon. Geol Soc Am Bull. 1994;106:840-54.

39. Larsen CF, Echelmeyer KA, Freymueller JT, Motyka RJ. Tide gauge records of uplift along the northern Pacific-North American plate boundary, 1937 to 2001. J Geophys Res Solid Earth. 2003;108.

40. Kato T. Secular and earthquake-related vertical crustal movements in Japan as deduced from tidal records (1951-1981). Tectonophysics. 1983;97:183-200.

41. Moucha R, Forte AM, Rowley DB, Mitrovica JX, Simmons NA, Grand SP. Dynamic topography and long-term sea-level variations: there is no such thing as a stable continental platform. Geology. 2008;271:101-8.

42. Rowley DB, Forte AM, Moucha R, Mitrovica JX, Simmons NA, Grand SP. Dynamic topography change of the eastern United States since 3 million years ago. Science (80- ). 2013;340:1560-3.

43. Rovere A, Hearty PJ, Austermann J, Mitrovica JX, Gale J, Moucha R, Forte AM, Raymo ME. Mid-Pliocene shorelines of the US Atlantic Coastal Plain - an improved elevation database with comparison to Earth model predictions. Earth Sci Rev. 2015;145:117-31.

44. Rovere A, Raymo ME, Mitrovica JX, Hearty PJ, O Leary MJ, Inglis JD (2014) The mid-Pliocene sea-level conundrum: glacial isostasy, eustasy and dynamic topography. Earth Planet Sci Lett 387:27-33

45. Rovere A, Raymo ME, Vacchi M, Lorscheid T, Stocchi P, GómezPujol L, Harris DL, Casella E, O'Leary MJ, Hearty PJ. The analysis of last interglacial (MIS 5e) relative sea-level indicators: reconstructing sea-level in a warmer world. Earth Sci Rev. 2016;159:404-27. Review on the use of Paleo RSL indicators to reconstruct Pleistocene sea level histories.

46. Brain MJ. Past, present and future perspectives of sediment compaction as a driver of relative sea level and coastal change. Curr Clim Chang Rep. 2016:1-11.
47. Marriner N, Flaux C, Morhange C, Kaniewski D. Nile Delta's sinking past: quantifiable links with Holocene compaction and climatedriven changes in sediment supply? Geology. 2012;40:1083-6.

48. Törnqvist TE, Wallace DJ, Storms JEA, Wallinga J, Van Dam RL, Blaauw M, Derksen MS, Klerks CJW, Meijneken C, Snijders EMA. Mississippi Delta subsidence primarily caused by compaction of Holocene strata. Nat Geosci. 2008;1:173-6.

49. Milliman J, Haq BU (1996) Sea-level rise and coastal subsidence: causes, consequences, and strategies. Springer Science \& Business Media

50. Dalca AV, Ferrier KL, Mitrovica JX, Perron JT, Milne GA, Creveling JR. On postglacial sea level-III. Incorporating sediment redistribution. Geophys J Int. 2013;194:45-60.

51. Adams PN, Opdyke ND, Jaeger JM. Isostatic uplift driven by karstification and sea-level oscillation: modeling landscape evolution in north Florida. Geology. 2010;38:531-4.

52. Lambeck K. Volcanic loading and isostasy. In: Hopley D, editor. Encycl. Mod. Coral reefs Struct. Form process. Dordrecht: Springer Netherlands; 2011. p. 1140-2.

53. Syvitski JPM, Kettner AJ, Overeem I, et al. Sinking deltas due to human activities. Nat Geosci. 2009;2:681-6.

54. Ericson JP, Vörösmarty CJ, Dingman SL, Ward LG, Meybeck M. Effective sea-level rise and deltas: causes of change and human dimension implications. Glob Planet Chang. 2006;50:63-82.

55. Chaussard E, Amelung F, Abidin H, Hong S-H. Sinking cities in Indonesia: ALOS PALSAR detects rapid subsidence due to groundwater and gas extraction. Remote Sens Environ. 2013;128:150-61.

56. Teatini P, Tosi L, Strozzi T. Quantitative evidence that compaction of Holocene sediments drives the present land subsidence of the Po Delta, Italy. J Geophys Res Solid Earth. 2011;116.

57. Cabanes C, Cazenave A, Le Provost C. Sea level rise during past 40 years determined from satellite and in situ observations. Science (80- ). 2001;294:840-2.

58. Shennan I, Horton B. Holocene land- and sea-level changes in Great Britain. J Quat Sci. 2002;17:511-26.

59. Vacchi M, Marriner N, Morhange C, Spada G, Fontana A, Rovere A. Multiproxy assessment of Holocene relative sea-level changes in the western Mediterranean: variability in the sea-level histories and redefinition of the isostatic signal. Earth Sci Rev. 2016;155:172-97.

60. Wöppelmann G, Pouvreau N, Coulomb A, Simon B, Woodworth PL. Tide gauge datum continuity at Brest since 1711: France's longest sea-level record. Geophys Res Lett. 2008;35.

61. Douglas BC. Global sea level rise. J Geophys Res Ocean. 1991;96: 6981-92.

62. Engelhart SE, Horton BP, Douglas BC, Peltier WR, Tornqvist TE. Spatial variability of late Holocene and 20th century sea-level rise along the Atlantic coast of the United States. Geology. 2009;37:1115-8.

63. Hay CC, Morrow E, Kopp RE, Mitrovica JX. Probabilistic reanalysis of twentieth-century sea-level rise. Nature. 2015;517:481-4.

64. Church JA, White NJ. Sea-level rise from the late 19th to the early 21st century. Surv Geophys. 2011;32:585-602.

65. Julia Pfeffer J, Allemand P. Contribution of vertical land motions to relative sea level variations: a global synthesis of multisatellite altimetry, tide gauge data and GPS measurements. Earth Planet Sci Lett. 2015;439:39-47.

66. Turner RE. Tide gauge records, water level rise, and subsidence in the northern Gulf of Mexico. Estuaries. 1991;14:139-47.

67. Cazenave A, Bonnefond P, Mercier F, Dominh K, Toumazou V. Sea level variations in the Mediterranean Sea and Black Sea from satellite altimetry and tide gauges. Glob Planet Chang. 2002;34:59-86.

68. Fu L-L, Cazenave A (2000) Satellite altimetry and earth sciences: a handbook of techniques and applications. Academic

69. Leuliette EW, Nerem RS, Mitchum GT. Calibration of TOPEX/ Poseidon and Jason altimeter data to construct a continuous record of mean sea level change. Mar Geod. 2004;27:79-94. 
70. Peltier WR, Luthcke SB. On the origins of Earth rotation anomalies: new insights on the basis of both "paleogeodetic" data and Gravity Recovery and Climate Experiment (GRACE) data. J Geophys Res Solid Earth. 2009;114.

71. Chambers DP. Observing seasonal steric sea level variations with GRACE and satellite altimetry. J Geophys Res Ocean. 2006;111.

72. Reager JT, Gardner AS, Famiglietti JS, Wiese DN, Eicker A, Lo M$\mathrm{H}$. A decade of sea level rise slowed by climate-driven hydrology. Science (80- ). 2016;351:699-703.

73. Stammer D, Cazenave A, Ponte RM, Tamisiea ME. Causes for contemporary regional sea level changes. Ann Rev Mar Sci. 2013;5:21-46.

74. Cazenave A, Dieng H-B, Meyssignac B, von Schuckmann K, Decharme B, Berthier E (2014) The rate of sea-level rise. Nat. Clim. Chang.

75. Gardner AS, Moholdt G, Cogley JG, et al. A reconciled estimate of glacier contributions to sea level rise: 2003 to 2009. Science (80- ). 2013;340:852-7.

76. Galassi G, Spada G. Sea-level rise in the Mediterranean Sea by 2050: roles of terrestrial ice melt, steric effects and glacial isostatic adjustment. Glob Planet Chang. 2014;123:55-66.

77. Lisiecki LE, Raymo ME (2005) A Pliocene-Pleistocene stack of 57 globally distributed benthic $\delta 180$ records. Paleoceanography 20

78. Grant KM, Rohling EJ, Ramsey CB, et al. Sea-level variability over five glacial cycles. Nat Commun. 2014;5.

79. Lambeck K, Antonioli F, Purcell A, Silenzi S. Sea-level change along the Italian coast for the past 10,000yr. Quat Sci Rev. 2004;23:1567-98.

80. Marriner N, Morhange C. Geoscience of ancient Mediterranean harbours. Earth Sci Rev. 2007;80:137-94.

81. Morhange C, Marriner N (2015) Archeological and biological relative sea-level indicators. Handbook of sea-level research. Wiley Online Library, pp 146-156

82. Auriemma R, Solinas E. Archaeological remains as sea level change markers: a review. Quat Int. 2009;206:134-46.

83. Rovere A, Antonioli F, Bianchi CN (2015) Fixed biological indicators. In: Shennan I, Long AJ, Horton BP (eds) Handbook of sealevel research. Wiley Online Library, pp 268-280
84. Kemp AC, Horton BP, Donnelly JP, Mann ME, Vermeer M, Rahmstorf S. Climate related sea-level variations over the past two millennia. Proc Natl Acad Sci. 2011;108:11017-22.

85. Dutton A, Carlson AE, Long AJ, Milne GA, Clark PU, DeConto R, Horton BP, Rahmstorf S, Raymo ME. Sea-level rise due to polar ice-sheet mass loss during past warm periods. Science. 2015;349: aaa4019.

86. Hearty PJ, Hollin JT, Neumann a. C, O’leary MJ, McCulloch M, O’Leary MJ (2007) Global sea-level fluctuations during the last interglaciation (MIS 5e). Quat Sci Rev 26:2090-2112

87. Mann T, Rovere A, Schöne T, Klicpera A, Stocchi P, Lukman M, Westphal $\mathrm{H}$. The magnitude of a mid-Holocene sea-level highstand in the Strait of Makassar. Geomorphology. 2016;257:155-63.

88. Hijma MP, Engelhart SE, Törnqvist TE, Horton BP, Hu P, Hill DF (2015) A protocol for a geological sea-level database. Handbook of sea-level research, Wiley Online Library, pp 536-553. Best practices to compile inventories of Holocene RSL indicators.

89. Horton BP, Engelhart SE, Hill DF, Kemp AC, Nikitina D, Miller $\mathrm{KG}$, Peltier WR. Influence of tidal-range change and sediment compaction on Holocene relative sea-level change in New Jersey, USA. J Quat Sci. 2013;28:403-11.

90. Dutton A, Lambeck K. Ice volume and sea level during the last interglacial. Science. 2012;337:216-9.

91. Meltzner AJ, Woodroffe CD (2015) Coral microatolls. Handbook of sea-level research, Wiley Online Library, pp 126-144

92. Hibbert FD, Rohling EJ, Dutton A, Williams FH, Chutcharavan PM, Zhao C, Tamisiea ME. Coral indicators of past sea-level change: a global repository of U-series dated benchmarks. Quat Sci Rev. 2016;145:1-56.

93. Medina-Elizalde M. A global compilation of coral sea-level benchmarks: implications and new challenges. Earth Planet Sci Lett. 2013;362:310-8.

94. Bosello F, Roson R, Tol RSJ. Economy-wide estimates of the implications of climate change: sea level rise. Environ Resour Econ. 2007;37:549-71.

95. Leatherman SP. Social and economic costs of sea level rise. Int Geophys. 2001;75:181-223. 